\title{
MAPPING INDONESIAN MUSLIM ORGANIZATIONS IN THE NETHERLANDS
}

\author{
Fachri Aidulsyah and Gusnelly \\ Research Center for Regional Resources \\ Indonesian Institute of Sciences, Jakarta, Indonesia \\ Email:fachryadul@gmail.com
}

\begin{abstract}
Since few years ago, Indonesian government have been concerning to gain many benefits from Indonesian diaspora in various regions in the world. There are many events and agendas provided by the government which are aimed to embrace many Indonesian diaspora for giving a great contribution towards their homelands. However, its vision for gaining attention from Indonesian diaspora tends to low because the government do not have Indonesian diaspora maps in details, comprehensive, as well as described by historical trajectory. This paper aims to understand the contribution of Indonesian Muslim diaspora by mapping the role of Indonesian Muslim Organizations in the Netherlands by socio-historical perspectives. The main reasons of the Netherlands as locus of this research are; Indonesian Muslim diaspora are the first actors who promoted Islam faces in this country since I92os and it also was acknowledged as one of the highest Muslim populated countries in Europe. Afterwards, this paper shows that there are numerous Indonesian Muslim organizations in the Netherlands from different perspectives, mazhabs, and backgrounds. Even though the government did not pillarize Indonesian Muslim organizations, albeit most of them have strong connections with some Muslim organizations in Indonesia, starting from Nahdhatul Ulama (NU) until Salafist Movement.
\end{abstract}

Keywords: Indonesian Diaspora, Muslim Organizations, the Netherlands

\begin{abstract}
Abstrak
Sejak beberapa tahun yang lalu, pemerintah Indonesia telah memperhatikan untuk mendapatkan banyak manfaat dari diaspora Indonesia di berbagai daerah di dunia. Ada banyak acara dan agenda yang disediakan oleh pemerintah yang bertujuan untuk merangkul banyak diaspora Indonesia untuk memberikan kontribusi besar terhadap tanah air mereka. Namun, visinya untuk mendapatkan perhatian dari diaspora Indonesia cenderung rendah karena pemerintah tidak memiliki peta diaspora Indonesia secara terperinci, komprehensif, serta dijelaskan oleh lintasan sejarah. Makalah ini bertujuan untuk memahami kontribusi diaspora Muslim Indonesia dengan memetakan peran Organisasi Muslim Indonesia di Belanda oleh perspektif sosial-historis. Alasan utama Belanda sebagai tempat penelitian ini adalah; Diaspora Muslim Indonesia adalah aktor pertama yang mempromosikan wajah Islam di negara ini sejak I920-an dan juga diakui sebagai salah satu negara dengan populasi Muslim tertinggi di Eropa. Setelah itu, makalah ini menunjukkan bahwa ada banyak organisasi Muslim Indonesia di Belanda dari berbagai sudut pandang, mazhab, dan latar belakang. Meskipun pemerintah tidak memprioritaskan organisasi Muslim Indonesia, meskipun sebagian besar dari mereka memiliki hubungan kuat dengan beberapa organisasi Muslim di Indonesia, mulai dari Nahdhatul Ulama (NU) hingga Gerakan Salafi.
\end{abstract}

Kata kunci: Diaspora Indonesia, Organisasi Muslim, Belanda 


\section{INTRODUCTION}

In the global era, the term of "diaspora" has been being discussed by numerous countries in the world. In general, there is mounting evidence that diasporas do indeed play important roles in promoting the development of their countries of origin or ancestry and these roles go far beyond the transfer of remittances (Migration Policy Institute, 2013). Due to diaspora's significance, most of developed countries in the world such as China, India, as well as Turkey took many advantages from their diasporas who have been spreading in various regions (Siddiqui and Tejada, 2014; Stowasser; 2002). Nowadays, India has been developing industrial technology sectors which were initiated by its prominent diaspora in digital technology sectors, such as Sundar Picay (CEO Google), Satya Nadella (CEO Microsoft), as well as Rajeev Suri (CEO Nokia) (IOM, 2009; MPI, 20I2; Nathan, 2013).

In term of Indonesia, the government has realized that there are many functions of diaspora for enriching the number of remittances, transfer of knowledge, as well as promoting soft-diplomacy. According to the data, the number of Indonesian diaspora in numerous regions in the world was predicted reached 8 million people, i.e. Malaysia (35\%), Saudi Arabia (I3\%), UAE (II\%), Netherlands (5), Singapore (5\%), Bangladesh (5\%), China (Hongkong (4\%), ect. (UN Desa, 2013; Muhidin and Utomo,2015; Indonesian Diaspora Network, 20I5). In term of remittance, the government have acknowledged that the data from Migration and Remittance Factbook 2016-World Bank showed that in 2014 the number of diaspora's transfer and transactions to Indonesia is up to $\$ 10,5$ billion or 136 trillion rupiah.

In term of soft-diplomacy, there are many Indonesian diasporas in various regions in the world have been promoting Indonesian cultures in International level. Moreover, some Indonesian diasporas also contribute to campaign their religious-cultures toward the world. In term of Islam, since I7-Igs centuries there are many Indonesian diasporas i.e. Ahmad Mirshad al-Batawi (I293-I353 H), Abdul Aziz al-Lasami (?-I390 H), Ahmad Khatib Al-Minangkabawi
(I3OI-I357 H), Abdusshomad Al-Falimbani (III6I203 H), Ahmad Yusuf Al-Makassari, Ahmad Arsyad al Banjari (II22-I227 H), etc were active to be famous ulama' in Islamic world and promoted the new model of Islam which is very viscous with Indonesian traditions. In the contemporary era, Nahdhatul Ulama (NU) which is the biggest Islamic community in Indonesia has succeeded to constitute NU's mazhabs which is condensed with tolerance virtues in conflict country, such as Afghanistan. Moreover, NU's diaspora also had succeeded to expand NU traditions and established NU branches in various continents, such as Asia (I2 branches), Africa (6 branches), America (I branch), Australia and Pacific (I branch), as well as Europe (7 branches) (Saiman, 20I9).

Theoretically, the promotion of Indonesian Islam in overseas which was led by diaspora should be defined as an expansion and the existence strengthening of diaspora's identity by practicing rituals and establishing numerous religious institutions outside their home country (Johnson, 2012 in Albrecht, 2016; Gusnelly, 20I8). Moreover, these realities should also be interpreted as a 'diaspora consciousness' which is conceived as a specific awareness, supposedly characteristic of people living 'here' and relating to a 'there': "Diaspora consciousness is entirely a product of cultures and histories in collision and dialogue (Baumann, 2000: 324). Therefore, according to Rebhun's perspective (2016) the promotion of Indonesian Islam should also be understood as a way to associate with a real or imagined original religious authority, which members have memories of their religious homeland and are strongly involved in social, cultural, and political matters towards the country. Finally, referring to Eisenlohr (in Albrecht et al 20I6) sometimes Indonesian Muslim diaspora also become a resource for long-distance political allegiances mobilized by trans-national or even global religious authorities.

According to the data above, this paper focuses to map the role of Indonesian Muslim organizations, its contributions and its connections towards global world and Indonesia as a homeland as well as original religious 
authority in the Netherlands by socio-historical perspectives. There are two reasons on how the Netherlands should be the main locus in this research, i.e. a) Diaspora Muslim Indonesia is the first actor that promoted Islam faces in the Netherlands since I920s (Rath, Meyer, and Sunier, I997; Ryad, 20I2; Poeze, 20I4 Stutje, 20I6);b) the Netherlands also was acknowledged as one of the highest Muslim populations in Europe. The data from Europe's Growing Muslim Population stated that in 2010 the number of Muslim population in the Netherland just reached 990,000 people. In 2016, the number of them had increased significantly that attained more than I,210.00o people, and was predicted that the number of Muslim population in the Netherlands in 2050 gained I,510.00o people (zero migration scenario) (PEW Research Center, 20I7).

\section{THE HISTORY OF (INDONESIAN) MUSLIM POPULATION IN THE NETHERLANDS}

Historically, many Muslim had arrived in North-Western Europe since the end of World War Il. This reality can be divided into three waves: between I945-1965 it was most often the ex-colonials who came to the former colonizing country. In the United Kingdom they were mostly from South Asian, East African and Nigerian Muslims. In France, the most Muslim communities originated from North and West Africa. In the Netherlands. They were from Indonesia ( 16,000$)$ and Javanese-Surinam $(34,000)$. The second wave was dominant in the period I965-1985, while unskilled and often illiterate migrant workers from North Africa and Turkey came to the rich countries of NorthWest Europe. The third wave, between I9 85 and 2005 consisted out of refugees from countries in disorder or in war. They were mostly among the better educated and experienced of their communities. Different with France and Britain, most Dutch Muslims did not originate from the former colonial territory (Steenbrink, n.d.). Statistically, Rath, Meyer, and Sunier (I997) showed that in I97I the number of Muslim population in the Netherlands just reached 50,000 people. In I980, the number of Muslim populations had increased five times as much that reached 235,000 people, and in 1996 the number of them had growth drastically which raise them up to 700,000 people. In 2017 , from $17,151,228$ Netherlands population, 5.I\% are Muslim, 23.6\% Roman Catholic, I4.9\% Protestant (includes Dutch Reformed 6.4\%, Protestant Church of The Netherlands 5.6\%, Calvinist 2.9\%), 5.6\% other, (includes Hindu, Buddhist, Jewish) and 50.7\% are none (World Factbook, 2019).

Since I970s and I980s, Muslim identity of migrant was demonstrated by establishing numerous religious institutions in various sectors, such as religious, social, education, media, as well as politic. All of these institutions were functioned for constituting Islamic faith, expanding Islamic values as well as advocating Muslim rights such as establishing mosque and Islamic school, praying and wearing Muslim fashion in the public space and company (Landman, I99I; Bommel, I992; Vertovec, 2002; Sunier and Landman, 2015). Meanwhile, most of Muslim communities in the Netherlands are obedient to the state Constitution which contains democratic principles, civic rights, as well as the separation between public and private, state and religion.

In term Indonesian diaspora, there are 2.1\% people who live in the Netherlands are Indonesian (including third and fourth generation). In 2004, out of the 8,400 Dutch citizens of (recent) Indonesian descent, 7392 were estimated as Muslims, related to the $88 \%$ Muslims of the Indonesian population (Steenbrink, n.d.: I). At the same time, a majority of former Indonesian Muslims has applied for Dutch passports and so the general number of Dutch Muslims of Indonesian origin is estimated at about $\mathbf{I} 6.000$ (Steenbrink, n.d.: I).

In term house of Worship, in I970 the number of Mosques in the Netherlands reached 5 Mosques, in I980, the number of it has grown up to Ioo Mosques, and a decade laterthe number of Mosques was 300 Mosques. Nowadays, the number of Mosques in the Netherlands is around 475 Mosques, which they were categorized by ethnic groups, i.e. 242 of mosques are Turkish, I7o Moroccans, 52 
Surinamese, and 2 Indonesians (Institute for Multicultural Affairs, 2010: 37; Interview with Nico Landman, March $12^{\text {th }}$ 20I9).

\section{Indonesian Muslim Organization in the Netherlands in Pre-Independence}

Furthermore, Indonesian Muslim diaspora in the Netherlands had constituted themselves into Islamic organization since preindependence of Indonesia. In 1932, there are some Indonesian Muslims in the Netherlands from various backgrounds such as students, houseboys, seamen and others, founded an PUI organization, Perkumpulan Islam, or Indonesian Islamic Association (in Dutch Indonesische Islamitische Vereniging). The organization was initiated by Ali Van Beetem, A Dutchman Ex- the Royal Netherlands East Indies Army (KNIL) who had converted to Islam, wanted to provide numerous Islamic activities for Indonesian Muslims in his home (Ryad, 20I2; 278; Poeze, 20I4). Moreover, the PUI was mainly active in the Hague; it began in I932 with sixty members but gradually grew to roughly 300 members around I940 (Bommel, I992: 26; Poeze, 20I4: 296; Stutje, 20I6: I30; Steenbrink, n.d.). In 1932 they negotiated with the local government to designate an Islamic section in the public cemetery of the Hague, and in 1935 PUl's members established a langgar at Hugo de Grootstraat 3I at the same city (Stutje, 2016: I32).

In the I950s migrant workers from Indonesia continued the PUI, but it was difficult for them to get new members: PUI was organised by low class migrant workers. Their own second generation did not continue the organization and most Indonesians who arrived after I950 did not find it attractive to join such a group. Still, in 1975 PUI was one of the founding members of the Union of Muslim Organizations in the Netherlands (Federatie van Moslim Organisaties in Nederland). In the early 2000 s very few still belonged to it, but at that time it still functioned as the administrator of the cemetery for Muslim in The Hague (Steenbrink, n.d.:2).

However, due to most of POI's members are came from lower class that has implicated to the difficulty of organization for associating with Islam organization in Europe or global level. Fortunately, Van Beetem had succeeded to solved these problems. As a representative of Muslim in the Netherlands, Van Beetem attended to European Muslim Congress in Geneva in I935 which was initiated by the well-known Lebanese pan-Islamic organizer Shakíb Arslán who was also part of the circles around Muhammad Rashíd Ridá and Amín AlHusayní. For Van Beetem, the congress provided the opportunity to request -half a year after the inauguration of the langgar-community building in The Hague -moral support for the construction of a proper mosque like the mosques in London, Berlin, Paris (Ryad, 2012: 301; Stutje, 2016: I38-139).

\section{Indonesian Muslim Organization in the Netherlands in New Order Era}

Since the last of ig6os, while the government had taken by Soeharto, the tension between the Netherlands and Indonesia as caused colonialism in the past began to dim. Therefore, at that times Indonesian government initiated to send many Indonesian students to continue their studies in the Netherlands. In I97I, some of these new arrivals established PPME, Persatuan Pemuda Islam se-Eropa (Union of Muslim Youth in Europe). At the first time, the establishment of PPME as the response to the absence of any organization for Moluccan Muslims who arrived earlier in the country since I950s (Bommel, I992; Hoek, I992; Steenbrink, n.d.; Sujadi, 20I7). We should acknowledge that even though most of Moluccan Muslims at the times were Ex-KNIL who already gained the citizenship from the Netherlands, albeit they also as a representation of Indonesian Muslim diaspora in the country (Hoek, I992).

On the other hand, the aim of the establishment of PPME is making spiritual association and facilitating Islamic education for Indonesian Muslim communities which is un-facilitated by the representation of Indonesian Government in the Netherlands. According to Sujadi (2017: 5-6), at a later time, PPME are providing many activities, such as facilitating to those who want to convert to Islam; daurah(intensive Islamic studies); istigotsah (appeal for God's protection and assistance); the publication of periodicals; 
organizing a program for pilgrimage to Mecca; the purchase of locations that function as places of worship and centre of activity; increasing attempts to encourage members to give financially or non-financially; inviting ulamas from Indonesia for ramadhan programmes; the commemoration of the Prophet's birth; sport days; and halal bihalal (a gathering for forgiving one another).

Until 2008, there were more or less 150 families involved PPME activities in The Hague, 6o families enrolled in PPME Rotterdam, 268 families have membership in PPME Amsterdam, I25 families have joined al-Ikhlash PPME, a splinter group of PPME Amsterdam, 40 families take part in religious activities run by PPME Heemskerk, 35 families are registered as members of PPME Breda-Tilburg. In total, in 2008 the number of families registered as PPME members in the Netherlands was approximately 678 (Sujadi, 20I7: I-2).

Since I September 1993, PPME has been registered as a vereniging (association) without a time limit on its existence. Since then, it has held the following activities. Having become an active member of the World Assembly of Muslim Youth (WAMY) in October 1994 as a result of its representatives regularly having participated in WAMY's gatherings since I977, on 2 July I995, PPME formed al-Moekminun [al-Mu'minūn, the Believers]. This group aimed to accommodate its Dutch-speaking members who wanted to study Islam. Consequently, Dutch speaking members instructed Dutchmen to improve the Islamic knowledge of those who did not speak Indonesian. Then, from September 1995 to April 1996, PPME was involved in purchasing a mosque specifically for the Indonesian Muslim community in the Netherlands. The Mosque al-Hikmah (Wisdom) was bought in I996. Since July of 1996, it has been under the management of the it for its weekly activities (Sujadi, 2017: 62-63). Today, members of PPME include professionals, unskilled laborers, business people, and pensioners. In addition, the organization continues to welcome students (Sujadi, 2017: 43).
In addition to PPME, a number of other organizations also have played significant roles for Indonesian Muslims in the Netherlands. Firstly, Keluarga Islam Delft (KID, Delft Muslim Family) was founded in the mid-I980s. KID was established by Indonesian Muslim students who continued their studies in graduate programs in at Delft University of Technology. KID organized a number of activities, such as organizing Friday prayers, the organizing of almsgiving, weekly general Islamic preaching, establishing a library, dawn preaching, short Islamic studies, as well as establishing a baitul maal[bayt al-māl] (division of financial affairs). Secondly, Indonensich Stichting Rotterdam/Nasuha Center,founded in I980s, accommodates some Islamic activities for Indonesian Muslim society in Rotterdam (Interview with Marko Lubeek, March I $3^{\text {th }}$ 20I9). Thirdly, Ikatan Cendekiawan Muslim Indonesia (ICMI, Association for Indonesian Muslim Intellectuals) in the Netherlands, founded in the early I990s, initially drew the attention of many Indonesian Muslims in the country. Leading Muslim figures, officials, and students involved themselves in running this new intellectual association (Sujadi, 20I7: 6-7).

On the other hand, some Indonesian Muslim diaspora also collaborate to maintain an Islamic organization with Dutch-Muslim, i.e. Muslim Information Centre (MIC) of Beeklan, the Hague. An Indonesian Muslim scholar, Dr. Sofyan Siregar who arrived in the early I980s in the Netherlands as a student of Islam in Egypt took a role for organizing many agendas of $\mathrm{MIC}$ under the director of MIC, Abdulwahid Van Bommel who well-known as a Dutch Muslim. Moreover, by routinely MIC published a popular quarterly (since I977) Qiblat, with MIC director as leading writer (Steenbrink, n.d.: 8).

Fourthly, on 3 April I989, at the height of the Rushdie debate, Sofyan Siregar left MIC and started his own centre; ICCN, the Islamic Cultural Centre in the Netherlands (Islamitisch Cultureel Centrum Nederland). Actually, ICCN had good relations with the government of Saudi Arabia and the international organisation Rabita 'alam Islami. ICCN was the sole Dutch agent for people who needed visa to go to Mecca for "umrah or hajj. On the other hand, 
it also started some prestigious publications and published its own Dutch translation of the Qur'an in 1996 and the selection of hadith by Imam Nawawi, Riyād al-sālihīn (Steenbrink, n.d.: 8).

Nowadays, ICCN has some routinize agendas, such as da'wa to Muslim prisoners in the Netherlands during ramadhan month by Arabic and Dutch, centre for information and advocacy that functioned for advocating some religious problems, i.e. the prohibition of wearing jilbab and burqa in public spaces, responding violence and terrorism which it related to Muslim society, as well as establishing majlis fatwa which it collaborated with Turkish and Moroccans. In national level, majles fatwa play a role to assign the beginning and the end of ramadhan month and stipulate the duration of prayer times during summer and winter. On the other hand, some ICCN members also participated to establish Stichting Platform Islamitice Organisation Rotterdam (SPOR) in the Netherlands (Interview with Hamdi Rofiefuddin, March 20 ${ }^{\text {th }}$ 2019).

Fifth, a quite peculiar activity that can be put under the label of the presence of Indonesian Muslims in the Netherlands is the publishing house Noer al-Ilm, started in 1993 by a Dutch lady, convert to Islam after her marriage to an Indonesian who studied engineering at Delft Technical University. Noer al-ilm publishes mostly translations of quite orthodox, not to say Wahhabi authors like Ibn Taimiyya, Sayid Qutb (the last volume on Juz 'Amma of his commentary Fī Zillāl al-Qư'ān), Yusuf Qardawi (Al-halāl wa al-harām fī al-islām). These books are very cheap: about $20 \%$ of prices that one would expect for such books in a Dutch bookshop. This proves that some large subsidies (from abroad) are given for these publications. Besides translations, Noer al-ilm also publishes original books about Islam for children, comics and some lighter works (Steenbrink, n.d.: 8).

\section{INDONESIAN MUSLIM ORGANIZATION IN THE NETHERLANDS IN REFORMATION ERA}

In the reformation era, there are numerous Islamic organizations which were established by Indonesian Muslim diaspora, and some of them are affiliated with Islamic organization, such as Pengurus Cabang Istimewa Muhammadiyah (PCIM) that established since 2006, Pengurus Cabang Istimewa Nahdhatul Ulama (PCINU, established 2015). However, even though in the first time the number of PCIM participants reached more than hundred members, albeit nowadays PCIM tend to non-active as caused most of Muhammadiyah participants in the Netherlands had returned to Indonesia (Interview Fitria, March $15^{\text {th }}$ 2019). In 20I9, there are just five persons who were active and became the administrator of the organization. In contrast, PCINU which was established later tend to very active and militants. There are more than 50 stakeholders of PCINU who provided many programs, such as pengajian tombo ati once a week for undocumented workers, pesantren kilat and Taman Pendidikan Al-Qur'an (TPA) for kids, making Lembaga Pertanian dan Lingkungan Hidup (LPLH-PCINU) which it functioned for giving information regarding fatwa of halal food as well as campaigning food security and sustainable agenda in Indonesia and the Netherlands. Furthermore, PCINU NL also collaborated with the Ministry of Religious Affairs of Indonesia for establishing Biennal Internation Conference for promoting Indonesian Islam which it very closes with tolerance and peaceful values once in two years. Moreover, this conference had succeeded to invite hundreds scholars and the representation of the government who concern in Islamic issues from various regions in the world. Afterwards, some of PCINU activists also making collaboration with International Organization for Migration (IOM) for advocating and empowering Indonesian undocumented workers in the Netherlands (Focus Group Discussion with PCINU's stakeholders, March II $^{\text {th }}$ 20I9). 
On the other hand, there are also Islamic organizations which it affiliated with political party, such as Pusat Informasi dan Pelayanan Partai Keadilan Sejahtera (PIP PKS, established 200I). In 2004, PIP PKS had succeed to pronounce PKS became the winner in Indonesian election in the Netherlands. However, nowadays PIP PKS tend to less active rather than PIP PKS in Germany and UK.

In term of charity, there is Indonesian Muslim charity organization in the Netherlads which is called Indonensische StichtingNederland (Isned NL). Isned NL which was established since 2004 has been collecting humanitarian donations from Indonesian Muslim diaspora in every region in the Netherlands and distributed them to some Indonesian provinces every year. In 2004, Isned NL had succeeded to amass charity which gained $€$ I0o, ooo for helping Aceh Tsunami victims. Currently, Isned NL cooperated with some Islamic charity organizations in Indonesia, such as PKPU, ACT, as well as Dompet Dhuafa (Interview with Didin Fahruddin, March II $^{\text {th }}$ 20I9).

Moreover, there are some Indonesian Muslim organizations in the Netherlands which were established by Indonesians who already stay there permanently, such as IndonesischNederlandsche Moslim Gemeenschap Amsterdam (Euromoslim, established 2005), Himpunan Masyarakat Muslim Indonesia (HIMMI Rotterdam, established 20I0), as well as Stichthing Generasi Baru (SGB, established 2008). Both of Euromoslim, HIMMI Rotterdam, and SGB already have the acknowledgment from the government. On the other hand, all of them also have a permanent small Islamic center then another organization (an exception for PPME Amsterdam which has established Masjid AlIkhlas Amsterdam or PPME The Hague which is based in Masjid Al-Hikmah The Hague). All of Euromoslim, HIMMI Rotterdam, as well as SGB have a regular recitation forum once a week, and some of them have Islamic consultation for a Dutchman who want to convert to Islam. Almost every year, in HIMMI Rotterdam there are IO-I2 Dutchmen convert to Islam (Interview Hamdi Rofiefuddin, March $20^{\text {th }}$ 2019). On the other hand, both of Euromoslim and SGB are also active to invite some ustadzs for giving Islamic lecturersin their communities. Most of ustadzs who were invited by Euromoslim are ustadzs from Salafist background, while SGB concerns to invite famous ustadzs from moderate backgrounds.

Moreover, due to the increasement of scholarship for Indonesian students to study in the Netherlands, it also has positive implications for establishing numerous Indonesian Islamic associations in various regions in the country, such as Keluarga Muslim Delft (KMD) in Delft, De Gromiest in Groningen, Pengajian Wageningen, Indonesian Moslems in Enschede Association(IMEA) in Enschede, Muslim Eindhoven (MUSIHOVEN) in Eindhoven, Keluarga Muslim Neijmegen (KEMUNI) in Neijmegen, and KAMIL Limburg Maastricht. Most of them also collaborate with Muslim Surinams and Moroccans for establishing some agendas, such as Idul Fitr and Idul Adha celebrations as well as making daily Islamic recitation in Turkish, Moroccan and Surinam Mosques. In term of KMD and Musihoven, due to many KMD and Musihoven's members are Indonesian Muslim expatriates, almost all of operational costs of the organization were funded by them. Currently, Musihoven has been processing the establishment of Islamic digital apps which provided many Muslim programs and chit chat spaces for Muslim society in the Netherlands.

\section{CONCLUSION}

Even though the number of Indonesian Muslim society in the Netherlands tends to lower than Turks, Moroccans, as well as Surinams, albeit they also contribute to took an important role in Muslim community in the Netherlands, starting from the establishment many Muslim associations and religious activities, translating and publishing Quran and numerous Islamic books in Dutch, advocating the people, and surely some of them have strong connections towards Muslim organizations in Indonesia.

Moreover, Indonesian Muslim organizations in the Netherlands which were established since I930s were classified into some categories, for instance, the organization which affiliated 
with Indonesian mainstreaming organizations, such as PCIM) and PCNU, affiliated with political party such as PIP PKS NL, affiliated with Indonesian Islamic charity organizations, such as Isned NL, Indonesian Muslim organizations which were established by Indonesian Muslim diaspora who had stayed in the Netherlands permanently, such as Himmi Rotterdam, SGB, PPME, Euromoslim etc., as well as Indonesian Muslim organization which were led by Indonesian Muslim students that have been spreading in various regions in the Netherlands.

\section{REFERENCES}

Albrecht, S. (20I6). Searching for the 'Homeland' of Islam: Concepts of Diaspora in Contemporary Islamic Discourse on Muslims in the West. Journal of Muslims in Europe, 5(1), I06-131. https://doi.org/IO.II63/22II7954-I234I32I

Albrecht, S., Boos, T., Deffner, V., Gebauer, M., \& Araújo, S. H. de. (2016). Editorial: Conceptualising 'Muslim Diaspora.' Journal of Muslims in Europe, 5(I), I-9. https://doi. org/Io.II63/22II7954-I234I3I6

Baumann, M. (2000). Diaspora: Genealogies of Semantics and Transcultural Comparison. Numen, 47(3), 313-337. JSTOR.

Central Intelligence Agency. (2019). The CIA World Factbook 20I9. Central Intelligence Agency.

Gusnelly. (2018). Kebebasan Beragama dan Hukum Penodaan Agama di Inggris. Dalam A. Mudzakir, Gusnelly, E. Budiwanti, \& P. N. Mulyasari (Ed.), Menuju Masyarakat Pasca-Sekuler:Agama dan Kewarganegaraan di Inggris. Penerbit Ombak. http://penerbitombak.com/product/ menuju-masyarakat-pasca-sekuler-agamadan-kewarganegaraan-di-inggris/

Institute for Multicultural Affairs. (2010). The position of Muslims in the Netherlands: Facts and Figures. FORUM - Institute for Multicultural Affairs.

Muhidin, S., \& Utomo, A. (2016). Global Indonesian Diaspora: How many are there and where are they? JAS (Journal of ASEAN Studies), 3(2), 93-IoI. https://doi.org/ı0.21512/jas.v3i2.847

Pew Research Center. (2017, November 29). Muslim Population Growth in Europe. Pew Research Center's Religion \& Public Life Project. https:// www.pewforum.org/2017/II/29/europesgrowing-muslim-population/
Poeze, H. A., Dijk, C., \& Meulen, I. van der. (2008). Di Negeri Penjajah: Orang Indonesia di Negeri Belanda, I600-1950. Kepustakaan Populer Gramedia.

Rath, J., Sunier, T., \& Meyer, A. (I997). Islam in The Netherlands: The Establishment of Islamic Institutions in A De-Pillarizing Society. Tijdschrift Voor Economische En Sociale Geografie / Journal of Economic and Social Geography, 88(4), 389-395.

Ryad, U. (20I2). Among the Believers in the Land of the Colonizer: Mohammed Ali van Beetem's Role Among the Indonesian Community in the Netherlands in the Interwar Period. Journal of Religion in Europe, 5(2), 273-310. https://doi.org/Io.II63/187489212X634780

Saiman, A. (2019, Mei 3). An Overview of Indonesian Muslim Diaspora. Presentation of Director of Center of Policy Analysis and Development on Asia Pacific and Africa Regions, Ministry of Foreign Affairs of the Republic of Indonesia, Jakarta.

Siddiqui, Z., \& Tejada, G. (2014). Development and Highly Skilled Migrants: Perspectives from the Indian Diaspora and Returnees. International Development Policy | Revue internationale de politique de développement, 5(5.2), Article 2. https://doi.org/ro.4000/ poldev.I720

Stowasser, B. F. (2002). The Turks in Germany: From Sojourners to Citizens. Dalam Y. Y. Haddad (Ed.), Muslims in the West: From Sojourners to Citizens (I edition). Oxford University Press USA.

Stutje, K. (2016). Indonesian Islam in Interwar Europe: Muslim Organizations in the Netherlands and Beyond. Muslims in Interwar Europe, I25-I5O. https://doi.org/I0.II63/9789004301979_007

Sujadi. (20I7). Persatuan Pemuda Muslim Se-Eropa: Identity, Encouragement for giving, and Network, I97I-2009 [Doctoral Thesis, Leiden University].https://openaccess.leidenuniv.nl/ handle/1887/50645

UN DESA. (2013). International migrant stock 2013: By destination and origin. United Nations Department of Economic and Social Affairs. https://www.un.org/en/development/desa/ population/migration/data/estimates2/ estimatesorigin.asp

World Bank. (2016). Migration and Remittances Factbook 2016, Third Edition. World Bank. https://openknowledge.worldbank.org/ handle/Io986/23743 


\section{Interviews}

Focus Group Discussion with PCINU's stakeholders, March IO $^{\text {th }} 2019$

Interview with Didin Fahruddin, March II $^{\text {th }} 2019$ in The Hague

Interview with Nico Landman, March $12^{\text {th }} 2019$ in Utrecht

Interview with Marko Lubeek, March $13^{\text {th }} 2019$ in Rotterdam

Interview with Hamdi Rofiefuddin, March $20^{\text {th }} 2019$ in The Hague 
